\title{
RESISTANCE OF TOMATO GENOTYPES WITH HIGH LEVEL OF ACYLSUGARS TO Tetranychus evansi Baker \& Pritchard
}

\author{
Juliano Tadeu Vilela de Resende ${ }^{*}$; Wilson Roberto Maluf ${ }^{2}$; Maria das Graças Cardoso ${ }^{3}$; \\ Marcos Ventura Faria ${ }^{1}$; Luciano Donizete Gonçalves ${ }^{2}$; Ildon Rodrigues do Nascimento ${ }^{1}$ \\ ${ }^{1}$ UNICENTRO - Depto. de Agronomia - C.P. 3010 - 85040-080 - Guarapuava, PR - Brasil. \\ ${ }_{3}^{2}$ UFLA - Depto. de Agricultura, C.P. 37 - 37200-000 - Lavras, MG - Brasil. \\ ${ }^{3}$ UFLA - Depto. de Química. \\ *Corresponding author $<$ jresende@unicentro.br>
}

\begin{abstract}
The Lycopersicon pennellii accession LA716 has been used as a source of arthropod pest resistance in tomato breeding programs due the high contents of acylsugars presents in its leaflets. We investigated the relationship between high foliar acylsugar contents and repellence to spider mite Tetranychus evansi in plants with contrasting acylsugar levels, selected from $\mathrm{F}_{2}$ and $\mathrm{BC}_{1} \mathrm{~F}_{2}\left(=\mathrm{F}_{2}\right.$ of the first backcross towards $L$. esculentum) generations derived from the interespecific cross $L$. esculentum 'TOM-584' $\times$ L. pennellii LA716. Mite resistance was assessed by a repellence test. Plants selected for high levels of acylsugars in leaflets had mite repellence levels similar to that of LA716. The high correlation confirmed the association between high acylsugar levels and mite repellence.

Key words: Lycopersicon esculentum, Lycopersicon pennellii, allelochemical, plant breeding, host plant resistance

\section{RESISTÊNCIADE GENÓTIPOS DE TOMATEIRO COMALTO TEOR DE ACILAÇÚCARES A Tetranychus evansi Baker \& Pritchard}

\begin{abstract}
RESUMO: O acesso de Lycopersicon pennellii LA716 tem sido utilizado em programas de melhoramento do tomateiro devido à sua resistência a artrópodos-pragas, mediada pela presença de acilaçúcares nos folíolos. Foi verificada a correlação entre o teor de acilaçúcares em folíolos de tomateiros e a repelência ao ácaro Tetranychus evansi Baker \& Pritchard. Foram selecionadas plantas contrastantes quanto aos níveis de acilaçúcares nos folíolos de populações $\mathrm{F}_{2}$ e $\mathrm{F}_{2} \mathrm{RC}_{1}\left(=\mathrm{F}_{2}\right.$ do primeiro retrocruzamento para Lycopersicon esculentum) do cruzamento interespecífico de L. esculentum TOM 584 (baixo teor de acilaçúcares) e L. pennellii LA 716 (alto teor). Foi realizado um teste de repelência ao ácaro T. evansi, tomando por base a distância percorrida pelos ácaros nos folíolos. Os genótipos selecionados para alto teor de acilaçúcares, em média, foram responsáveis por reduções significativas nas distâncias percorridas pelos ácaros sobre a superfície do folíolo. A repelência ao ácaro T. evansi exercida pelas plantas selecionadas para alto teor de acilaçúcares deu-se de forma semelhante àquela conferida pelo genitor LA-716. As magnitudes das correlações encontradas confirmam a associação entre altos teores do aleloquímico e a repelência ao ácaro.

Palavras-chave: Lycopersicon esculentum, Lycopersicon pennellii, aleloquímicos, melhoramento genético, resistência da planta hospedeira
\end{abstract}

\section{INTRODUCTION}

Many sources of resistance to tomato arthropod pests have been identified in wild taxa of the genus Lycopersicon, like $L$. pennellii, $L$. hirsutum e $L$. peruvianum (França et al., 1984a; 1984b). The $L$. pennellii accession LA716 has shown resistance to a large number of pests, including spider mites of the genus Tetranychus (Gentile et al., 1968; 1969; Juvik et al., 1982; Gonçalves, 2006). In genotypes derived from L pennellii LA716, the resistance to pests is attributed mainly to the presence of acylsugars in the leaflets (Ponti et al., 1975; Berlinger \& Dahan, 1984; França et al., 1984a; Resende, 2003; Resende et al., 2006), although some other non-identified factors certainly contribute to the resistance. Recessive alleles are responsible for the high levels of acylsugars in Lycopersicon pennellii LA 716. Nevertheless, the presence of modifying genes was not excluded (Resende et al., 2002a).

Acylsugars are viscous allelochemicals, which are basically a mixture of glucose and sucrose esters esterified to fatty acids, playing an important role in the resistance to tomato pests (Fobes et al., 1985). 
Resende et al. (2006) and Azevedo et al. (2003) verified reduction in the oviposition of Tuta absoluta in genotypes with high contents of acylsugars and Resende et al. (2002b) reported the antibiosis effect on Bemisia argentifolli. In the mite of the genus Tetranychus the acylsugars act as repellent, probably due to their toxic activity (Gonçalves et al., 2006).

Cultivated tomatoes do not accumulate high levels of acylsugars in the leaflets. While acylsugars are encountered mainly in L. pennellii, their transfer to the cultivated tomato, L. esculentum, would contribute in breeding programs to increase levels of pest resistance in this commercial species (Resende et al., 2002a). The present study reports on the relationship between foliar acylsugars contents and repellence to spider mite Tetranychus evansi, in previously selected tomato genotypes obtained from an interspecific cross between L. pennellii LA716 and Lycopersicon esculentum 'TOM-584'.

\section{MATERIAL AND METHODS}

Segregating generations were obtained from an interspecific cross between L. pennellii LA716 (pollen source; wild accession with highest level of acylsugars and source of resistance to pests; obtained from the Tomato Genetics Stock Center/ University of California, Davis, CA, USA) and Lycopersicon esculentum 'TOM-584' (female parent; tospovirus-resistant breeding line, with a genetic background similar to the standard open-pollinated Brazilian cultivar 'Santa Clara'; with low level of acylsugars). Seeds of the parental lines were sowed in 128-cell tray speedling type spray filled with a commercial substrate. Fifteen days after, 40 plants from the male parent and 30 plants from the female parent were transplanted to a greenhouse. $\mathrm{F}_{1}$ generation seeds were obtained by artificial crossing with manual emasculation and pollination during flowering period.

The $\mathrm{F}_{1}$ plants were grown in the same conditions used for the parents, differing only in the final establishment, in which was used polyethylene $5 \mathrm{~L}$ vases in the greenhouse. The $\mathrm{F}_{2}$ seeds were obtained from the self-fertilization of $F_{1}$ plants. Two hundred, fifty-six $\mathrm{F}_{2}$ plants were transplanted to $500 \mathrm{~mL}$ vases and kept in a greenhouse. The acylsugars level of each $\mathrm{F}_{2}$ plant was estimated based on the analysis of expanded leaflets samples, according to the methodology described by Resende et al. (2002a). Four plants selected for high level of acylsugars in $\mathrm{F}_{2}$ population (BPX-370 pl\#10, BPX-370 pl\#25, BPX-370 pl\#30, BPX-370 pl\#79) were backcrossed to the recurrent parent ('TOM-584'). Twelve plants of the recurrent parent were kept in the greenhouse in $5 \mathrm{~L}$ plastic vases containing 2:1 soil-sand mixture and $1.8 \mathrm{~kg}$ NPK $4-14-8 / 100 \mathrm{~kg}$ substratum, with a drip system irrigation. These plants were artificially fertilized with pollen from the clones selected for high levels of acylsugars in $\mathrm{F}_{2}$ generation. Fruits were separately collected and seeds were identified according to the male parent, establishing $4 \mathrm{BC}_{1} \mathrm{~F}_{1}$ populations. The $\mathrm{BC}_{1} \mathrm{~F}_{2}$ seeds were obtained from the self-fertilization of $\mathrm{BC}_{1} \mathrm{~F}_{1}$ plants. From 600 plants ( 150 plants of each $\mathrm{BC}_{1} \mathrm{~F}_{2}$ population) six plants were selected, including $\mathrm{BPX}-370 \mathrm{~B}$ pl\#25-271, BPX-370B pl\#30-275, BPX-370B pl\#30380, BPX-370B pl\#79-278 (selected for high level of acylsugars) and BPX-370B pl $\# 30-02, \mathrm{BPX}-370 \mathrm{~B} \mathrm{pl} \# 30$ 142 (selected for low level of acylsugars), according to the methodology described by Resende et al. (2002a). These genotypes selected in $\mathrm{F}_{2}$ and $\mathrm{BC}_{1} \mathrm{~F}_{2}$ generations were cloned via rooted axillary shoot cuttings.

Two trials were performed to evaluate the resistance (repellence) tests to T. evansi, using the bioassay proposed by Weston \& Snyder (1990). In the first trail the four genotypes selected for high level of acylsugars (described above) and two genotypes selected for low level (BPX-370pl\#232 and BPX$370 \mathrm{pl}$ 226) from the $\mathrm{F}_{2}$ population were evaluated along with the parental genotypes 'TOM-584' (susceptible control) and LA-716 (resistant control), and the hybrid $\mathrm{F}_{1}($ 'TOM-584' $\times$ LA 716), with a total of nine treatments. In the second trail the six selected genotypes from the $\mathrm{BC}_{1} \mathrm{~F}_{2}$ (described above) with contrasting levels of acylsugar in the leaflets were evaluated along with the parents, using the same bioassay, in four replications.

The spider mites employed in the bioassays were collected from naturally infested sweet potato (Ipomoea batatas) plants kept in greenhouse. In both bioassays, fully expanded leaflets with similar sizes were removed from the apical region of flowering plants. The bioassays were carried out in an environmental chamber at $16 \pm 1{ }^{\circ} \mathrm{C}$ and a relative humidity $(\mathrm{RH})$ of $64 \pm 4 \%$, with a $12 \mathrm{~h}$-photoperiod, in four replications. One leaflet of each selected genotype was attached to a sheet of styrofoam with a methallic thumbtack $(9 \mathrm{~mm} \varnothing)$ placed in the center of an adaxial leaflet surface. The leaflets were randomly placed on the styrofoam sheet, and comprised on replication. Ten female spider mites were transferred with a fine artist's brush to each thumbtack. Distances traveled by mites from thumbtack center were measured after 20, 40 and 60 minutes. This bioassay is based on the principle that higher the level of allelochemicals (acylsugars) in the genotype is, lower the mite displacement on the leaf surface. Mites that stayed on the thumbtack were considered to have traveled a distance equal to zero. 
A group of previously planned contrasts comparing mite movement on leaves of genotypes with low and high acylsugar contents was estimated. A correlation analysis was performed to verify the relationship between the distances of mite displacement onto the selected genotypes and their respective acylsugar contents. In the first bioassay, data from 'TOM-584', LA716 and the $\mathrm{F}_{1}\left({ }^{\prime} \mathrm{TOM}-584\right.$ ' $\times$ LA-716) were not included in the correlation analysis, but they were analyzed separately through an analysis of variance and Duncan's test $(P<0.05)$, to confirm whether the thumbtack bioassay was able to detect differences in mite repellence between the control treatments. Analyses were performed using the statistical software SISVAR (Ferreira, 2000).

\section{RESULTS AND DISCUSSION}

The mean distances traveled by the spider mites onto the leaflets of $F_{1}$ ('TOM-584' $\times$ LA-716) and genotypes selected for high level of acylsugars in $\mathrm{F}_{2}$ population (BPX-370pl\#25, BPX-370pl\#30 and BPX-370pl\#79) did not differ from the distances traveled onto the wild accession LA-716 (Duncan test, $P<0.05$ ) (Table 1). On the other side, generally, the distances traveled by the mites onto the leaflets of the selected genotypes for low levels of acylsugars were close to those traveled onto the leaflets of the 'TOM584' genotype, and the BPX-370pl\#226 genotype did not differ from the commercial parent at 40 and 60 minutes.

The estimatives of the contrast 'low $v s$ high acylsugar $\mathrm{F}_{2}$ genotypes' (Table 1), as for the average distances travelled by the mites, were positive and significant indicating that, in average, the genotype selection based on the level of acylsugar in leaflets was efficient in the mite repellence (Table 1). The correlation values estimated between the acylsugars concentration in leaflets of $\mathrm{F}_{2}$ selected genotypes and the distances traveled by the mite $T$. evansi after 40 minutes $(-0.838)$ and 60 minutes $(-0.771)$, demonstrated that the distances traveled onto leaflets surface were significantly shorter in genotypes with high levels of acylsugars (Table 1). Distances after 40 and 60 minutes were negatively correlated against the levels of acylsugars in leaflets and the increase of repellence to mite was an indirect reply to the selection for high levels of acylsugars.

On average, the $\mathrm{BC}_{1} \mathrm{~F}_{2}$ genotypes selected for high level of acylsugars had a reduction in distances walked by the mites onto the leaflet surface, at 40 and 60 minutes, compared to the genotypes selected for low level, according to the estimative of the contrast 'high level genotypes vs low level genotypes' (Table 2). Genotypes that presented high levels of acylsugars in leaflets (BPX-370pl\#25-271, BPX370pl\#30-275, BPX-370pl\#30-380 and BPX-370pl\#79278) were more efficient in repelling mites which were

Table 1 - Average distances traveled by the Tetranychus evansi after 20, 40 and 60 minutes onto the adaxial leaflet surface of L. esculentum 'TOM-584', L. pennellii LA 716, $\mathrm{F}_{1}$ ('TOM-584' $\times$ LA-716) and of clones selected from population $\mathrm{F}_{2}$ ('TOM-584' $\times$ LA-716) and correlations between the average distances and the levels of acylsugars. $\mathrm{T}=16 \pm 1^{\circ} \mathrm{C}$; $\mathrm{RH}=64 \pm 4 \%$.

\begin{tabular}{|c|c|c|c|c|}
\hline \multirow{2}{*}{ Genotype } & \multirow[t]{2}{*}{ Level of acylsugars } & \multicolumn{3}{|c|}{$\begin{array}{l}\text { Distance traveled by the spider mites onto the } \\
\text { adaxial leaflets surface after }\end{array}$} \\
\hline & & $20 \min$ & $40 \mathrm{~min}$ & $60 \mathrm{~min}$ \\
\hline & $\mathrm{nmol} \mathrm{cm} \mathrm{cm}^{-2}$ & \multicolumn{3}{|c|}{ - } \\
\hline 'TOM-584' & $28.3 \pm 4.2 \mathrm{cde}$ & $11.0 \pm 2.3 \mathrm{a}$ & $13.4 \pm 3.7 \mathrm{a}$ & $12.4 \pm 0.9 \mathrm{a}$ \\
\hline LA-716 & $63.8 \pm 3.7 \mathrm{bc}$ & $1.8 \pm 0.2 \mathrm{~d}$ & $2.2 \pm 0.6 \mathrm{~d}$ & $2.6 \pm 0.6 \mathrm{e}$ \\
\hline F1('TOM-584' × LA-716) & $31.9 \pm 5.8 \mathrm{cde}$ & $1.9 \pm 0.3 \mathrm{~d}$ & $2.7 \pm 0.6 \mathrm{~d}$ & $2.8 \pm 0.3 \mathrm{e}$ \\
\hline BPX-370pl\#232 (Low 1) & $14.5 \pm 3.9 \mathrm{e}$ & $4.9 \pm 1.2 \mathrm{bc}$ & $7.6 \pm 2.1 \mathrm{bc}$ & $7.9 \pm 2.6 \mathrm{bcd}$ \\
\hline BPX-370pl\#226 (Low 2) & $20.6 \pm 4.1 \mathrm{de}$ & $7.6 \pm 0.7 b$ & $9.3 \pm 1.2 \mathrm{ab}$ & $9.9 \pm 1.1 \mathrm{ab}$ \\
\hline BPX-370pl\#10 (High 1) & $60.8 \pm 6.3 \mathrm{bcd}$ & $6.9 \pm 0.9 \mathrm{~b}$ & $7.4 \pm 0.6 \mathrm{bc}$ & $9.3 \pm 0.8 \mathrm{abc}$ \\
\hline BPX-370pl\#25 (High 2) & $78.6 \pm 5.2 b$ & $3.7 \pm 0.7 \mathrm{~cd}$ & $3.6 \pm 0.5 \mathrm{~cd}$ & $4.3 \pm 0.4 \mathrm{de}$ \\
\hline BPX-370pl\#30 (High 3) & $131.4 \pm 4.6 \mathrm{a}$ & $3.9 \pm 0.4 \mathrm{~cd}$ & $4.7 \pm 0.9 \mathrm{~cd}$ & $5.7 \pm 0.9 \mathrm{cde}$ \\
\hline BPX-370pl\#79 (High 4) & $136.3 \pm 3.7 \mathrm{a}$ & $3.2 \pm 0.6 \mathrm{~cd}$ & $3.4 \pm 1.1 \mathrm{~cd}$ & $4.0 \pm 1.3 \mathrm{e}$ \\
\hline \multicolumn{2}{|c|}{ Contrast estimate: low vs high acylsugar $\mathrm{F}_{2}$ genotypes } & $1.8 *$ & $3.7 * *$ & $3.1 * *$ \\
\hline \multicolumn{2}{|c|}{$\begin{array}{l}\text { Linear correlation }(\mathrm{r}) \text { : distance traveled } v s \text { acylsugar levels in the } \\
\mathrm{F}_{2} \text { genotypes }\end{array}$} & $-0.714^{\mathrm{ns}}$ & $-0.838 *$ & $-0.771 *$ \\
\hline
\end{tabular}

Means followed by the same letter, in the columns, do not differ (Duncan test, $P<0.05$ ). ${ }^{*}, * *=$ significant by Student $t$-test at $P<0.05$ and $P<0.01$, respectively. 
Table 2 - Levels of acylsugar in leaflets, average distances traveled by the Tetranychus evansi on the adaxial leaflet surface and correlations and contrasts estimatives of eight tomato genotypes. $\mathrm{T}=16 \pm 1^{\circ} \mathrm{C} ; \mathrm{RH}=64 \pm 4 \% ; 12 \mathrm{~h}$ photoperiod.

\begin{tabular}{|c|c|c|c|c|}
\hline \multirow{2}{*}{ Genotype } & \multirow{2}{*}{$\begin{array}{l}\text { Level of } \\
\text { acylsugars }\end{array}$} & \multicolumn{3}{|c|}{$\begin{array}{c}\text { Distance traveled by the mites onto leaflet } \\
\text { surface after }\end{array}$} \\
\hline & & $20 \mathrm{~min}$ & $40 \mathrm{~min}$ & $60 \mathrm{~min}$ \\
\hline & $\mathrm{nmol} \mathrm{cm} \mathrm{cm}^{-2}$ & \multicolumn{3}{|c|}{ (- } \\
\hline 'TOM-584' & $7.5 \pm 1.2 b$ & $19.8 \pm 0.4 \mathrm{a}$ & $17.1 \pm 0.7 \mathrm{a}$ & $19.1 \pm 0.7 \mathrm{a}$ \\
\hline LA-716 & $32.6 \pm 3.9 \mathrm{a}$ & $2.6 \pm 0.3 b$ & $2.9 \pm 0.5 \mathrm{~d}$ & $2.5 \pm 2.0 \mathrm{~d}$ \\
\hline BPX-370Bpl\#30-142 (Low1) & $4.8 \pm 1.0 \mathrm{~b}$ & $10.0 \pm 1.4 \mathrm{ab}$ & $10.8 \pm 1.1 \mathrm{abc}$ & $12.2 \pm 0.9 \mathrm{~b}$ \\
\hline BPX-370Bpl\#30-02 (Low2) & $4.9 \pm 0.8 b$ & $10.3 \pm 2.4 \mathrm{ab}$ & $12.9 \pm 1.8 \mathrm{ab}$ & $11.0 \pm 2.1 \mathrm{~b}$ \\
\hline BPX-370Bpl\#25-271 (High1) & $36.5 \pm 3.4 \mathrm{a}$ & $9.7 \pm 1.0 \mathrm{ab}$ & $9.1 \pm 2.3 \mathrm{bcd}$ & $9.1 \pm 1.6 \mathrm{bc}$ \\
\hline BPX-370Bpl\#30-275 (High2) & $43.2 \pm 0.7 \mathrm{a}$ & $3.6 \pm 0.9 \mathrm{~b}$ & $3.2 \pm 1.6 \mathrm{~d}$ & $3.2 \pm 1.6 \mathrm{~cd}$ \\
\hline BPX-370Bpl\#30-380 (High3) & $38.2 \pm 1.6 \mathrm{a}$ & $9.7 \pm 0.4 \mathrm{ab}$ & $9.7 \pm 0.8 \mathrm{bcd}$ & $8.1 \pm 1.7 \mathrm{bcd}$ \\
\hline BPX-370Bpl\#79-278 (High4) & $40.1 \pm 1.3 \mathrm{a}$ & $7.3 \pm 1.9 \mathrm{~b}$ & $5.3 \pm 2.6 \mathrm{~cd}$ & $6.0 \pm 1.2 \mathrm{bcd}$ \\
\hline \multirow{2}{*}{ Contrast } & & \multicolumn{3}{|c|}{ Estimate } \\
\hline & & $20 \min$ & $40 \mathrm{~min}$ & $60 \mathrm{~min}$ \\
\hline 'TOM-584' vs LA-716 & & $8.62 * *$ & $7.08 * *$ & $8.28 * *$ \\
\hline high level genotypes vs low level genotypes & & $-2.58^{\mathrm{ns}}$ & $-5.02 *$ & $-5.02 * *$ \\
\hline LA-716 vs high level genotypes & & $-5.00^{\mathrm{ns}}$ & $-3.85^{\text {ns }}$ & $-4.07^{\mathrm{ns}}$ \\
\hline LA-716 vs low level genotypes & & $-7.58^{\text {ns }}$ & $-8.87 * *$ & $9.08 * *$ \\
\hline 'TOM-584' vs high level genotypes & & $12.23 *$ & $10.30 * *$ & $12.50 * *$ \\
\hline 'TOM-584' vs low level genotypes & & $9.65 *$ & $5.28^{\mathrm{ns}}$ & $7.48 * *$ \\
\hline $\begin{array}{l}\text { Linear correlation }(\mathrm{r}) \text { : distances traveled } v s \text {. } \\
\text { level of acylsugars in the } \mathrm{BC}_{1} \mathrm{~F}_{2} \text { genotypes }\end{array}$ & & $-0.614^{\mathrm{ns}}$ & $-0.789 *$ & $-0.854 *$ \\
\hline
\end{tabular}

Means followed by the same letters, in the columns, do not differ (Duncan test, $P<0.05$ ). *** significant at $1 \%$ and $5 \%$ respectively by $\mathrm{F}$ test.

traveling. These genotypes were not different from the wild accession LA-716 (Duncan test, $P<0.05$ ). The estimative of the contrast 'LA-716 vs high level genotypes' were not significant, indicating that the selection of plants with high contents of acylsugars was efficient, as though they seemed to be similar to the parent LA-716 within the mite $T$. evansi repellence. The negative estimative of contrast 'LA-716 vs low level genotypes' and positive ones of contrast 'TOM-584 vs high level genotypes', confirm the efficiency of the selection based on the levels of acylsugars in mite repellence (Table 2).

The correlation values obtained between the distances travelled by the mites and the level of acylsugars at 40 minutes $(-0.789)$ and 60 minutes $(-0.854)$ were negative (Table 2$)$. The correlation values ensure the association between the high level of the allelochemical and the repellence to spider mites. Similar negative correlations were also related for the mite repelence limited by other allelochemicals: 2-tridecanon in genotypes derived from L. hirsutum var glabratum PI-134417 (Gonçalves et al., 1998; Aragão, 1998) and zingiberen in genotypes derived from L. hirsutum var hirsutum PI-127826 (Maluf et al., 2001).

Like the $\mathrm{BC}_{1} \mathrm{~F}_{2}$ genotypes, the $\mathrm{F}_{2}$ genotypes were selected on the respective assays, and this selection was only based on their level of acylsugars in leaflets. The negative correlations found between the levels of acylsugars and the average distance traveled by mites on $\mathrm{F}_{2}$ genotypes, indicate that the selection for high levels of acylsugars clearly increases the resistance level (repellence) to spider mite T. evansi.

The selected genotypes for high level of acylsugars in leaflets, in $\mathrm{F}_{2}$ and $\mathrm{BC}_{1} \mathrm{~F}_{2}$ populations from the crossing 'TOM-584' $\times$ LA716, were very expressive in showing resistance to $T$. evansi. The selected genotypes for high levels of acylsugars in populations $\mathrm{BC}_{1} \mathrm{~F}_{2}$ (BPX-370Bpl\#25-271, BPX-370Bpl\#30-275, $\mathrm{BPX}-370 \mathrm{Bpl} \# 30-380$ and $\mathrm{BPX}-370 \mathrm{Bpl} \# 79-278$ ) are promising in the breeding program, due to the results obtained in the resistance assays. It is presumable that the acylsugars act as resistance mechanisms of antibiosis type, complying with the results obtained by Goffreda et al. (1989), Hawthorne et al. (1992), Rodrigues et al. (1993), Juvik et al. (1994), Liedl et al. (1995) and Pamplona (2001) for many arthropods- 
pests, showing the indirect genetic gains relative to resistance, when a direct selection for high levels of acylsugars in leaflets is performed.

\section{CONCLUSIONS}

The presence of high levels of acylsugars in tomato leaflets is related to repellence to T. evansi. The direct selection in segregating populations derived from the interespecific crossing 'TOM-584' $\times$ LA-716 allows to obtain plants that are resistant to T. evansi.

\section{REFERENCES}

ARAGÃO, C.A. Tricomas foliares associados à resistência ao ácaro rajado em linhagens de tomateiro com alto teor de 2-tridecanona nos folíolos. Lavras: UFLA, 1998. 71p. Dissertação (Mestrado).

AZEVEDO, S.M.; FARIA, M.V.; MALUF, W.R.; OLIVEIRA, A.C.B.; FREITAS, J.A. Zingiberene-mediated resistance to the South American tomato pinworm. Euphytica, v.134, p.347-351, 2003.

BERLINGER, M.J.; DAHAN, R. Resistance to the tobacco whitefly. Bemisia tabaci, in tomato and related species: a quick screening method. Bulletin IOBC/WPRS, v.7, p.39-40, 1984.

FERREIRA, D.F. Análises estatísticas por meio do Sisvar para Windows versão 4.0. In:. REUNIÃO ANUAL DA REGIÃO BRASILEIRA DA SOCIEDADE INTERNACIONAL DE BIOMETRIA, 45., São Carlos, 2000. Anais. São Carlos: SIB, 2000. p.255-258.

FOBES, J.F.; MUDD, J.B.; MARSDEN, M.P.F. Epicuticular lipid acumulation on the leaves of Lycopersicon pennellii (Corr.) D'Arcy e Lycopersicon esculentum Mill. Plant Physiology, v.77, p.567-570, 1985.

FRANÇA, F.A.; MALUF, W.R.; ROSSI, P.E.F.; MIRANDA, J.F.C.; COELHO, M.C.F. Avaliação e seleção em tomate visando resistência à traça do tomateiro. In: CONGRESSO BRASILEIRO DE OlERICUlTURA, 3., Jaboticabal, 1984. Resumos. Jaboticabal: Sociedade de Olericultura do Brasil, 1984a. p.143.

FRANÇA, F.A.; MALUF, W.R.; ROSSI, P.E.F.; MIRANDA, J.F.C.; COELHO, M.C.F. Resistência em tomate à traça-do-tomateiro. In: CONGRESSO BRASILEIRO DE ENTOMOLOGIA, 9., Londrina, 1984. Resumos. Londrina: SEB, 1984b. p.124.

GENTILE, A.G.; WEBB, R.E.; STONER, A.K. Resistance in Lycopersicon and Solanum species to the potato aphid. Journal of Economic Entomology, v.61, p.1152-1154, 1968.

GOFFREDA, J.C.; MUTSCHLER, M.A.; AVÉ, D.A.; TINGEY, W.M.; STEFFENS, J.C. Aphid deterrence by glucose esters in glandular trichome exudate of wild tomato, Lycopersicon pennellii. Journal of Chemical Ecology, v.15, p.2135-2147, 1989.

GONÇALVES, L. D. Herança do teor de acilaçúcares em genótipos de tomateiro e sua relação com tricomas foliares e repelência ao ácaro Tetrayichus evansi. Lavras: UFLA, 2006. 85p. Tese (Doutorado).

GONÇALVES, L.D.; MALUF, W.R.; CARDOSO, M.G.; RESENDE, J.T.V.; CASTRO, E.M.; SANTOS, N.M.; NASCIMENTO, I.R.; FARIA, M.F. Zingibereno, tricomas foliares e sua ação na repelência a Tetranychus evansi em tomateiros derivados do cruzamento Lycopersicon esculentum x L. hirsutum var. hirsutum. Pesquisa Agropecuária Brasileira, v.41, p.267273, 2006.

GONÇALVES, M.I.F.; MALUF, W.R.; GOMES, L.A.A.; BARBOSA, L.V. Variation of 2-tridecanone level in tomato plant leaflets and resistance to two mites species (Tetranychus sp.). Euphytica, v.104, p.33-38, 1998.
HAWTHORNE, D.J.; SHAPIRO, J.A.; TINGEY, W.M.; MUTSCHLER, M.A. Trichome-borne and artificially applied acylsugars of wild tomato deter feeding and ovoposition of the leafminer Liriomyza trifolii. Entomologia Experimentalis et Applicata, v.65, p.65-73, 1992.

JUVIK, J.A.; BERLINGER, M.J.; BEN-DAVID, T.; RUDICH, J. Resistance among accessions of the genera Lycopersicon and Solanum to four of the main insect pest in Israel. Phytoparasitica, v.10, p.145-156, 1982.

JUVIK, J.A.; SHAPIRO, J.A.; YOUNG, T.E., MUTSCHLER, M.A. Acylglucose from wild tomato alters behavior and reduce growth and survival of Helicoverpa zea and Spodoptera exigua (Lepidoptera: Noctuidae). Journal of Economic Entomology, v.87, p.482-492, 1994.

LIEDL, B.E.; LAWSON, D.M.; WHITE, K.K.; SHAPIRO, J.A.; COHEN, D.E.; CARSON, W.G.; TRUMBLE, J.T.; MEITSCLER, M.A. Acylsugars of wild tomato Lycopersicon pennelli alters settling and reduces ovposition of Bemisia argentifolii (Homoptera: Aleyrodidae). Journal of Economic Entomology, v.88, p.742-748, 1995.

MALUF, W.R.; CAMPOS, G.A.; CARDOSO, M.G. Relationships between trichome types and spider mite (Tetranychus evansi) repellence in tomatoes with respect to foliar zingiberene contents. Euphytica, v.121, p.73-80, 2001.

PAMPLONA, A.M.S.R. Avaliação de genotipos de tomate Lycopersicon ssp. Com diferentes concentrações de acilaçúcares, quanto a resistência a Bemisia tabaci (Gennadius, 1889) (Hemitera: Aleyrodidae). Lavras: UFLA, 2001. 98p. Dissertação (Mestrado).

PONTI, O.M.B.; PET, G.; HOGENBOOM, N.G. Resistance to the glasshouse whitefly (Trialeurodeos vaporariorum Westw) in tomato (Lycopersicon esculentum Mill) and related species. Euphytica, v.24, p.645-649, 1975.

RESENDE, J.T.V. Resistência a artrópodos-pragas, mediada por acilaçúcares em tomateiros obtidos do cruzamento interespecífico de Lycopersicon esculentum Mill 'TOM 584' x Lycopersicon pennellii 'LA 716'. Lavras: UFLA, 2003. 91p. Tese (Doutorado).

RESENDE, J.T.V.; CARDOSO, M.G.; MALUF, W.R.; SANTOS, C.D.; GONÇALVES, L.D.; RESENDE, L.V.; NAVES, F.O. Método colorimétrico para quantificação de acilaçúcar em genótipos de tomateiro. Ciência e Agrotecnologia, v.26, p.1204-1208, $2002 \mathrm{a}$.

RESENDE, J.T.V.; MALUF, W.R.; FARIA, M.V; GONÇALVES, L.D., VARGAS, P.F.; RESENDE, F.V.; NAVES, F.O. Ovoposição e desenvolvimento de ninfas de mosca branca Bemisia argentifolii em função de acilaçúcares presentes nos folíolos de tomateiro.In: CONGRESSO BRASILEIRO DE OLERICULTURA, Uberlândia, 2002. Resumos. Uberlândia: Associação Brasileira de Horticultura, 2002b. p.426.

RESENDE, J.T.V.; MALUF, W.R.; FARIA, M.V.; NASCIMENTO, I.R.; PFANN, A.Z. Acylsugars in tomato leaflets confer resistance to the south american tomato pinworm, Tuta absoluta meyr. Scientia Agricola v.63, p.20-25, 2006.

RODRIGUES, A.E.; TINGEY, W.M.; MUTSCHLER, M.A. Acylsugars of Lycopersicon pennelli deter settling and feeding of the green peach aphid (Homoptera: Aphididae). Journal of Economic Entomology, v.86, p.34-49, 1993.

WESTON, P.A.; SNYDER, J.C. Thumbtack bioassay: a quick method of measuring plant resistance to twospotted spider mites (Acari: Tetranychidae). Journal of Economic Entomology, v.83, p.501-504, 1990.

Received January 09, 2006

Accepted September 18, 2007 